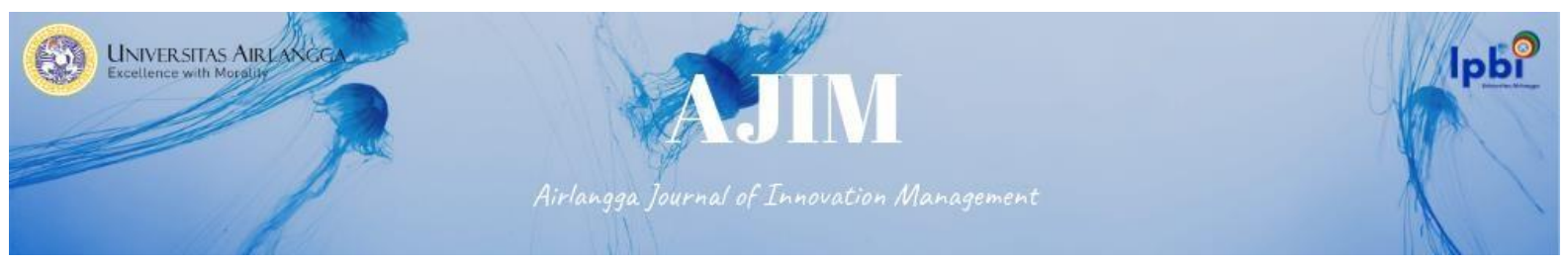

Vol. 2 No.1 Juni 2021

e-ISSN: 2722-5062

DOI : 10.20473/ajim.vvii.26630

\title{
THE ROLE OF CROWDFUNDING BASED DONATION MECHANISM IN AL-QUR'AN EDUCATION DEVELOPMENT
}

\author{
Uci Wulansari ${ }^{a}, *$, Achsania Hendratmi ${ }^{\text {b }}$ \\ ${ }^{\mathrm{a}, \mathrm{b}}$ Islamic Economics Department, Faculty Economic and Business, Universitas Airlangga, Surabaya \\ *Corresponding e-mail : uci.wulansari-2016@feb.uair.ac.id
}

\begin{abstract}
Crowdfunding mechanism in fundraising activities has experienced rapid development these recent years in various parts of the world. This requires philanthropic institutions to make digital innovations in their fundraising activities. This study aims to determine the role of crowdfunding-based donation mechanism in the advancement of Al-Qur'an education with a case study of tabungamal.id platform. The research method used is a qualitative approach with an explanatory case study method. Data collection techniques using direct interviews and observation. The mechanism of tabungamal.id was identified based on crowdfunding intermediaries function proposed by Philipp Haas et al, namely lot size transformation, risk transformation, and information transformation. The results of this study indicate that crowdfunding-based donation mechanism at tabungamal.id has roles in advancing $\mathrm{Al}$ Qur'an education, including reducing education disparities between economic classes and regions, supporting innovation in Al-Qur'an learning, and increasing community participation in advancement of Al-Qur'an education. These findings can be implemented by Islamic philanthropic institutions in developing a crowdfunding-based donation mechanism to optimize role of Islamic philanthropic institutions in digital era.
\end{abstract}

Keywords: Financial Technology, Crowdfunding Based Donation, Fundraising, Islamic Philanthropic, Education

\section{Introduction.}

Education is an instrument to alleviate poverty. An educational improvement is a form of increasing one's ability to compete for a better life in future (Ustama, 2009). In Indonesia, education still faces problems both in quantity and quality. This is supported by data on dropout rate which has increased by 34\% from the 2016/2017 school year to 2019/2020 (Kemendikbud, 2020). Apart from formal educational institutions, there are also various Islamic educational institutions. Initially, Islamic education was only in scope of society where learning was carried out in households, kutabs, and mosques that were running on a scientific and spiritual basis intending to practice religious teachings properly and correctly (Muslimin, 2004).

Based on data from official website of Directorate of Diniyah and Pondok Pesantren Education (2020) recorded that Islamic educational institutions in Indonesia consisting of 28,194 pondok 


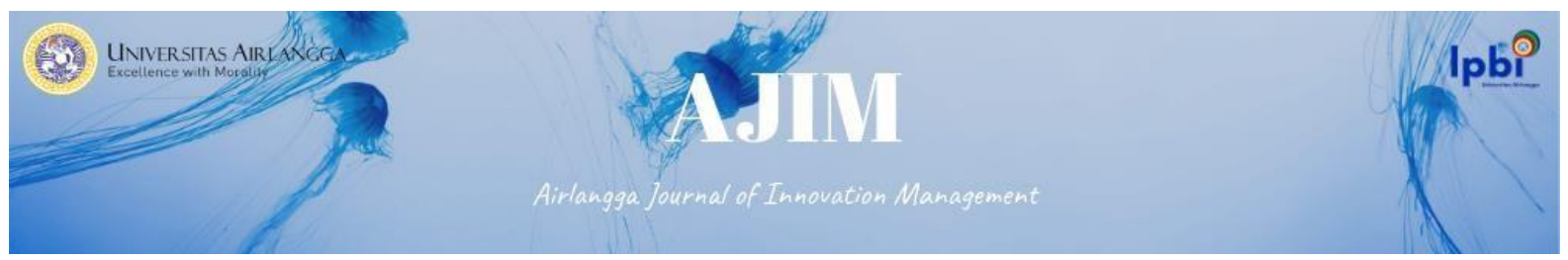

pesantren (Islamic boarding school), 84,966 Madrasah Diniyah Takmiliyah, 135,130 Qur'an education, 74 formal diniyah education, 88 muadalah education, and $35 \mathrm{ma}$ 'had aly. Al-Qur'an educational institutions have largest number of other Islamic educational institutions, this shows an important role of Al-Qur'an education in society. Al-Qur'an education not only about can read but also implement Qur'an in daily life. The success of Al-Qur'an education has implications for changing students' characters towards virtuous people with a divine spirit (Ratnawati, Abidin, \& Zulfikar, 2020). Besides an important role of Al-Qur'an education, it turns out that $54 \%$ of Muslim population in Indonesia is still blind to reading Al-Qur'an (Yusuf, 2017).

Al-Qur'an education institutions also face a variety of problems and challenges as well as formal education, such as facilities and infrastructure of some institutions that are not adequate, management of government institutions that are not so well structured, to minimal quantity and quality of teachers (Yahya, 2015). In addition, problems of qur'an education in industrial era 4.0 include monotonous learning methods of Qur'an, improper learning strategies of Qur'an, lack of infrastructure that supports Qur'an learning, no technological transformation and innovation in Qur'an learning, lack of professional educators, and lack of support from community (Ratnawati, Abidin, \& Zulfikar, 2020).

Cost of education becomes main background of problems in field of education. Households with lower-class economies have difficulty meeting basic household needs, especially for education. Badan Statistik Indonesia (BPS) statistics (2020) also show family's economic relationship with level of education of students, where lower economic status of household, the lower level of education that can be completed. The same is also experienced by Islamic educational institutions such as pesantren, where operational costs of pesantren come from tuition fees while students mostly come from the lower economy (Ja'far, 2018). Although government has provided various forms of subsidies and tuition assistance, cost barriers are still a problem that is attached to education.

The complexity of problems in the education field is the reason philanthropy supports the advancement of the education sector. The role of philanthropic institutions in education is also evidenced by thousands of pesantren in Indonesia that use philanthropic funds to develop education institutions (Latief, 2013). Islamic philanthropy funds aimed at education have considerable potential, with a total distribution of more than 1.2 trillion rupiahs or around 19.3 percent of total funds distribution, and are in third place after humanitarian and da'wah fields (BAZNAS, 2020). However, recipients of funds for this education programs are still relatively low, only 1.8 million people or 7.9 percent of total recipients of ZISWAF funds (BAZNAS, 2020). The potential of Islamic philanthropic funds the education field provides hope for lower-class economic households to improve their welfare through improvements and enhancement of education quality.

Despite this potential, Islamic philanthropic institutions often face various challenges and main obstacles in fundraising. Some studies show low fundraising rates caused by low public perception and trust in Islamic philanthropic institutions (Mubarok dan Fanani, 2014; Canggih et al, 2017; Hafiduddin, 2011; Wahid et al, 2009). This is due to lack of openness of institutions in management and distribution of funds, so muzakki prefer to distribute their zakat directly to mustahik in neighborhood where they live (Ascarya \& Yumanita, 2018). But as technology evolves, philanthropic activities are already being managed modernly, with more sophisticated fundraising and management models to address these challenges (Latief, 2013).

One of the fundraising models applied by Islamic philanthropic institutions is donation crowdfunding. The growth of crowdfunding market are impressive, not only growing in quantity but also complexity and diversity of model (infoDev, 2013). In donation crowdfunding, donors do not receive a refund from fundraiser because it is purely done to provide support for various social project 


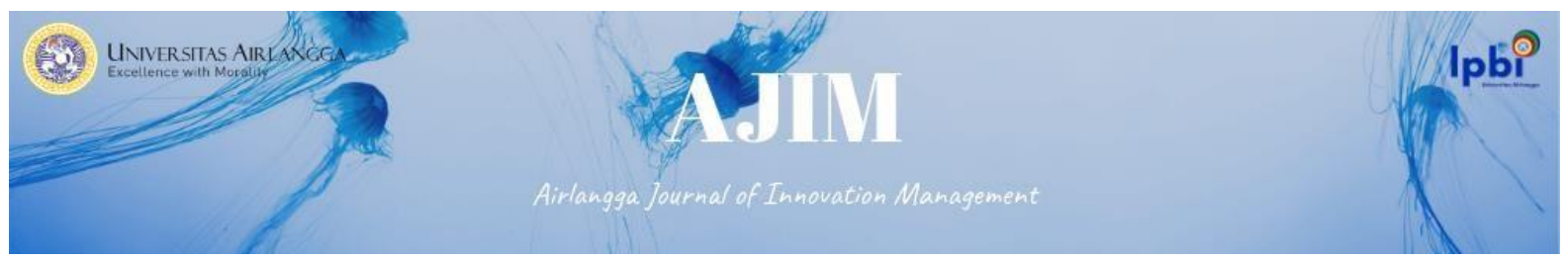

actions. One of Islamic philanthropic institutions that use crowdfunding-based donation mechanism is LAZIS Nurul Falah within platform tabungamal.id. tabungamal.id platform focuses on funding Qur'an's educational programs. Crowdfunding mechanism was chosen by tabungamal.id because it can collect donations as well as provide information about Qur'an's educational programs to public.

There has been a lot of research on use of online fundraising methods in Islamic philanthropic institutions but still limited research related to use of crowdfunding mechanisms as a method of fundraising Islamic philanthropic institutions. Meanwhile, previous research has covered legal and regulation of crowdfunding-based donation (Ulya, 2018); potential crowdfunding in collection of Islamic philanthropic funds for poverty alleviation (Manara, Permata, \& Pranjoto, 2018); and factors that influence the decision to donate through crowdfunding platforms (Zulfian, 2020). In addition, there has been no research related to role of crowdfunding mechanisms in advancement of Qur'an education. This study aims to find out crowdfunding-based donation mechanism in tabungamal.id and its role in supporting advancement of Qur'an education.

\section{Literature Review}

\section{Islamic Philanthropic}

Philanthropy in Islamic perspective is generosity or good deeds based on faith as fundamental ethical teaching in Islam (Linge, 2015). In Indonesia, development of Islamic philanthropic institutions was initiated by two religious institutions, namely Mosque and Pesantren (Bahjatulloh, 2016). Then appeared formal institutions such as the Badan Amil Zakat Nasional (BAZNAS), Lembaga Amil Zakat (LAZ), Baitul Maal wa Tamwil (BMT), where managing non-profit funds sourced from zakat, infaq, alms, and waqf (ZISWAF) (Kasdi, 2016). Research from (Ascarya \& Yumanita, 2018) shows the various problems faced by Islamic philanthropic institutions in their fundraising activities, as follows:

1. Internal problems of Islamic philanthropic institutions, including a large number of Amil Zakat Institutions (LAZ), high promotional costs, low effectiveness of zakat utilization programs, a low synergy between zakat stakeholders, and limited human resources of amil zakat (Huda \& et al, 2014).

2. External problems of Islamic philanthropic institutions, including lack of transparency and accountability in management of zakat funds, thus affecting level of public trust, where zakat is distributed (Huda \& et al, 2014).

3. System problems, regulatory support from government to proactively implement UU No. 23 Tahun 2011 about zakat (Ascarya \& Yumanita, 2018).

\section{Crowdfunding}

Hendratmi et al (2019) explain crowdfunding mechanism serves as an online intermediary that facilitates process of transferring funds from parties that have capital to parties in need of capital. There is a difference between crowdfunding and online fundraising, where crowdfunding focuses on a project or program that requires funds (InfoDev, 2013). Other distinguishing characteristics are presence of fundraising targets, target of funds to be collected, and target time of fundraising.

One crowdfunding model is crowdfunding-based donation. Crowdfunding-based donation have main characters that there is no return from fundraisers and do not have financing risks. Crowdfunding donations have principle of including three stakeholders described in figure 5 (Gierczak, Bretschneider, Haas, Blohm, \& Leimeister, 2015). Funding mechanism on crowdfunding donations according to Haas et al (2014) using principle of keep-it-all is that any funds raised during campaign period will still be distributed and not returned to donors. 


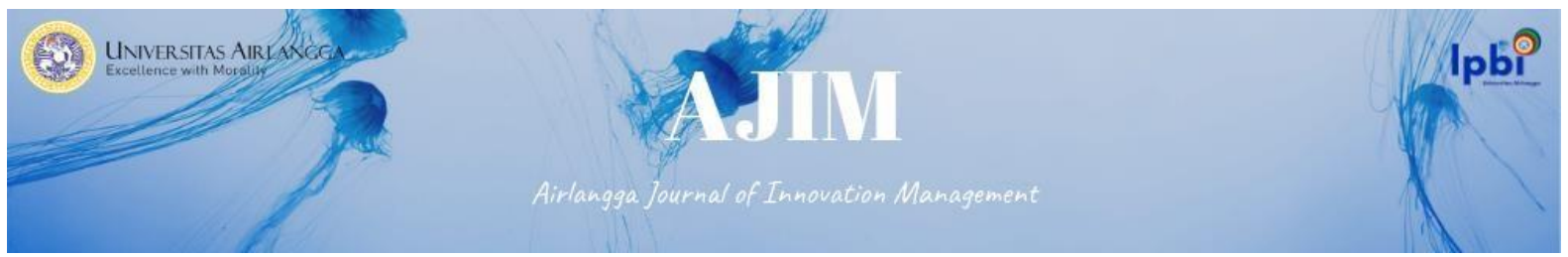

Unlike traditional financial intermediaries, crowdfunding platforms do not borrow, collect, or lend money through their accounts, but their function is more focused on providing information to minimize existing risks (Gierczak, Bretschneider, Haas, Blohm, \& Leimeister, 2015). Crowdfunding serves as an intermediary that brings together fundraisers and donors. Haas et al (2014) explained that crowdfunding has 3 intermediary functions namely Lot Size Transformation, Risk Transformation, and Information Transformation. This is explained in table 3 below:

Table 1

Crowdfunding Intermediaries Functions

\begin{tabular}{|c|c|}
\hline Function & Crowdfunding Platform \\
\hline $\begin{array}{l}\text { Lot Size } \\
\text { Transformation }\end{array}$ & $\begin{array}{l}\text { Matching capital-giving and -seeking agents (Belleflamme et al. 2013; Mollick } \\
\text { 2014; Schwienbacher and Larralde 2012) } \\
\text { - Providing mechanisms for payment, exchange of capital, and returns like } \\
\text { electronic markets (Bakos, 1998) } \\
\text { - Bridging capital-giving and capital-seeking agents overcoming time, geographies } \\
\text { or industry boundaries (Agrawal et al. 2010; Bakos 1998) } \\
\text { - Regulating demand by applying specialized funding mechanisms (Mitra and } \\
\text { Gilbert, 2014) }\end{array}$ \\
\hline $\begin{array}{l}\text { Risk } \\
\text { Transformation }\end{array}$ & $\begin{array}{l}\text { - Assessing credits of capital-seeking agents } \\
\text { - } \quad \text { Pre-selecting investment opportunities (projects) } \\
\text { - } \quad \text { Acting as neutral, trustworthy, objective partner, ensuring integrity (Bakos 1998) }\end{array}$ \\
\hline $\begin{array}{l}\text { Information } \\
\text { Transformation }\end{array}$ & $\begin{array}{l}\text { - Bundling information (Burtch et al, 2013) } \\
\text { - Providing information about investment opportunities (projects) for capital-giving } \\
\text { agents (Ahlers et al, 2012; Mitra and Gilbert 2014) } \\
\text { - Acting as electronic market place enabling capital-seeking and -giving agents to } \\
\text { exchange information about investment opportunities and returns (Bakos, 1998; } \\
\text { Mahadevan, 2000) } \\
\text { - Enabling formation of relationships beetwen agents, which is a major source for } \\
\text { information and trust (Lin et al, 2013; Zvilichovsky et al, 2013) }\end{array}$ \\
\hline
\end{tabular}

Source: (Haas, Blohm, \& Leimeister, 2014)

\section{Methods/Materials}

\section{Research Approach}

This study used qualitative approach using explanatory case study method. Explanatory case study method seeks to gather findings of field data facts that can corroborate or prove hypotheses and know correlation process of a phenomenon (Yin, 2016). Reason use of explanatory case study method is because this study aims to explain the correlation of crowdfunding mechanism and advancement of Qur'anic education.

The study also used a single case study. A single case study is applied if researchers only want to research something (e.g. one person from a group) or a group to explore new things with more careful research (Yin, 2016). The single case study is chosen because it can describe a phenomenon in more detail and depth. In this study, single case study is considered more able to provide comprehensive information about role of crowdfunding donations in supporting advancement of Qur'an education. 


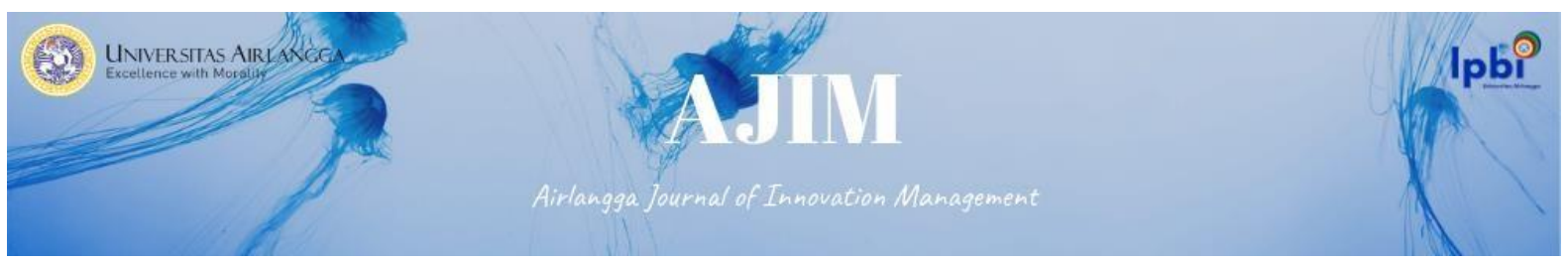

\section{Types and Data Sources}

The source and type of data in this study consist of primary and secondary data. Primary data obtained from informants. Key Informant is LAZIS Nurul Falah's Online Fundraising Supervisor and director of tabungamal.id. Informant can provide information related to funding process from beginning of campaigner applying for program until disbursement of funds in tabungamal.id. 2nd Informant is tabungamal's web developer. The second informant was chosen because it can explain the mechanism of tabungamal.id from platform's point of view. Such as uploading programs on platform, payment methods, and others. The 3th and 4th informants are two campaigners on tabungamal.id that recommended by LAZIS Nurul Falah. This campaigner's criteria is that has been fundraising on tabungamal.id platform. The 5th and 6th Informants are donors of tabungamal.id recommended by LAZIS Nurul Falah. The criteria for this donor is to have donated the tabungamal.id platform.

While secondary data in this study was obtained from magazines, platforms, social media, and supporting documents such as LAZIS Nurul Falah's annual report and tabungamal.id's report.

\section{Unit of Analysis}

The unit of analysis in this study is crowdfunding intermediary functions (Haas, Blohm, \& Leimeister, 2014) that will be able to describe overall crowdfunding mechanism of tabungamal.id as follows:

a. Lot size transformation: process of matching needs of fundraisers with donors and providing mechanisms to enable successful donations

b. Risk transformation: process of assessing and selecting programs from fundraisers

c. Information transformation: process of submitting campaign information to donors and fundraisers.

\section{Data Collection Procedure}

Data collection is done in two ways, namely:

1. Literature Study

The literature study was conducted to collect secondary data needed in this study. Secondary data collection is carried out through journals, magazines, platforms, reports on both performance and finance, and others.

2. Field Study

Field studies are carried out in two ways, namely:

a. Interview

The interview technique used in this research is in-depth interviews. Technically, interviews were conducted offline or face-to-face at the LAZIS Nurul Falah office at Jalan Ketintang Timur PPT Gang VB, Surabaya for Informants 1 and 2, while other informants were conducted online due to limited distance and PSBB appeal by the government due to the COVID 19 pandemic.

b. Observation

Observations in this study are used to obtain information directly in field by observing tabungamal.id platform. Another form of observation is by trying to become donors and volunteers in tabungamal.id. 


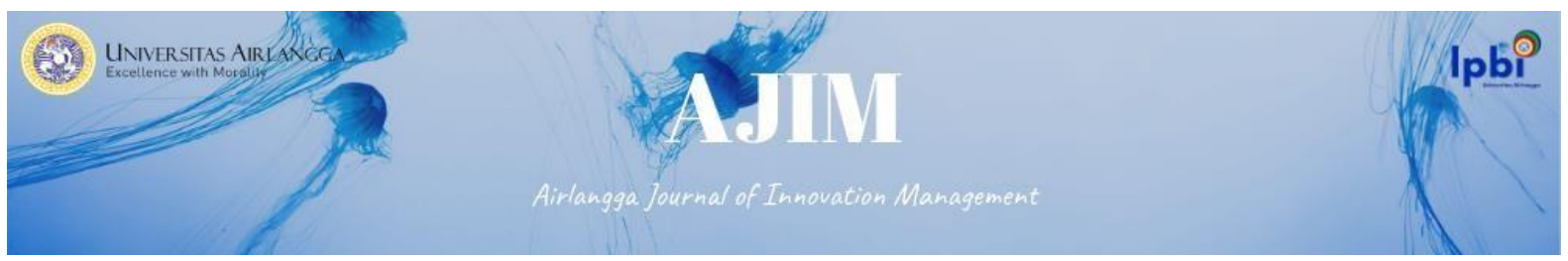

\section{Analysis Technique}

Analysis technique in this study is explanation building. Explanation building is an iterative process to build an explanation of what happened in a case study (Yin, 2016). Analysis technique is intended to build an explanation of role of mechanism of crowdfunding donations in advancement of education of Qur'an and to prove research proposition that mechanism of crowdfunding donations plays a role in advancement of education of the Qur'an.

\section{Data Validation Techniques}

This study used triangulation of data sources. Triangulation is a data validation technique used during field research to corroborate findings with facts built through two or more different sources (Yin, 2016). Checking validity of data is done by interview to tabungamal.id (directors, web developers, donors, and fundraisers), making direct observations on the platform, and through written reports from tabungamal.id.

\section{Results and Discussion}

\section{Crowdfunding Intermediaries Mechanism}

Discussion of tabungamal.id mechanism is shown through 3 intermediary crowdfunding functions, namely lot size transformation, risk transformation, and information transformation.

\section{A. Lot Size Transformation}

Lot size transformation is crowdfunding function as a bridge that connects and matches needs of fundraisers and donors by providing mechanisms that will enable successful funding (Haas, Blohm, \& Leimeister, 2014). Programs that can campaign on tabungamal.id platforms are programs related to Qur'an education programs. This is intended as a form of product differentiation in broad crowdfunding market. tabungamal.id takes crowdfunding niche market potential at Qur'an education field. There are four types of programs on tabungamal.id platform, namely: (1) scholarships, for student education costs; (2) charity, for students and teachers welfare; (3) waqf, to provide Al-Qur'an learning equipment; (4) humanity, for disaster relief experienced by students or teachers.

tabungamal.id platform is open to public. Donors and campaigners are from individuals or institutions. The form of support channeled consists of two types, materials and volunteers. 

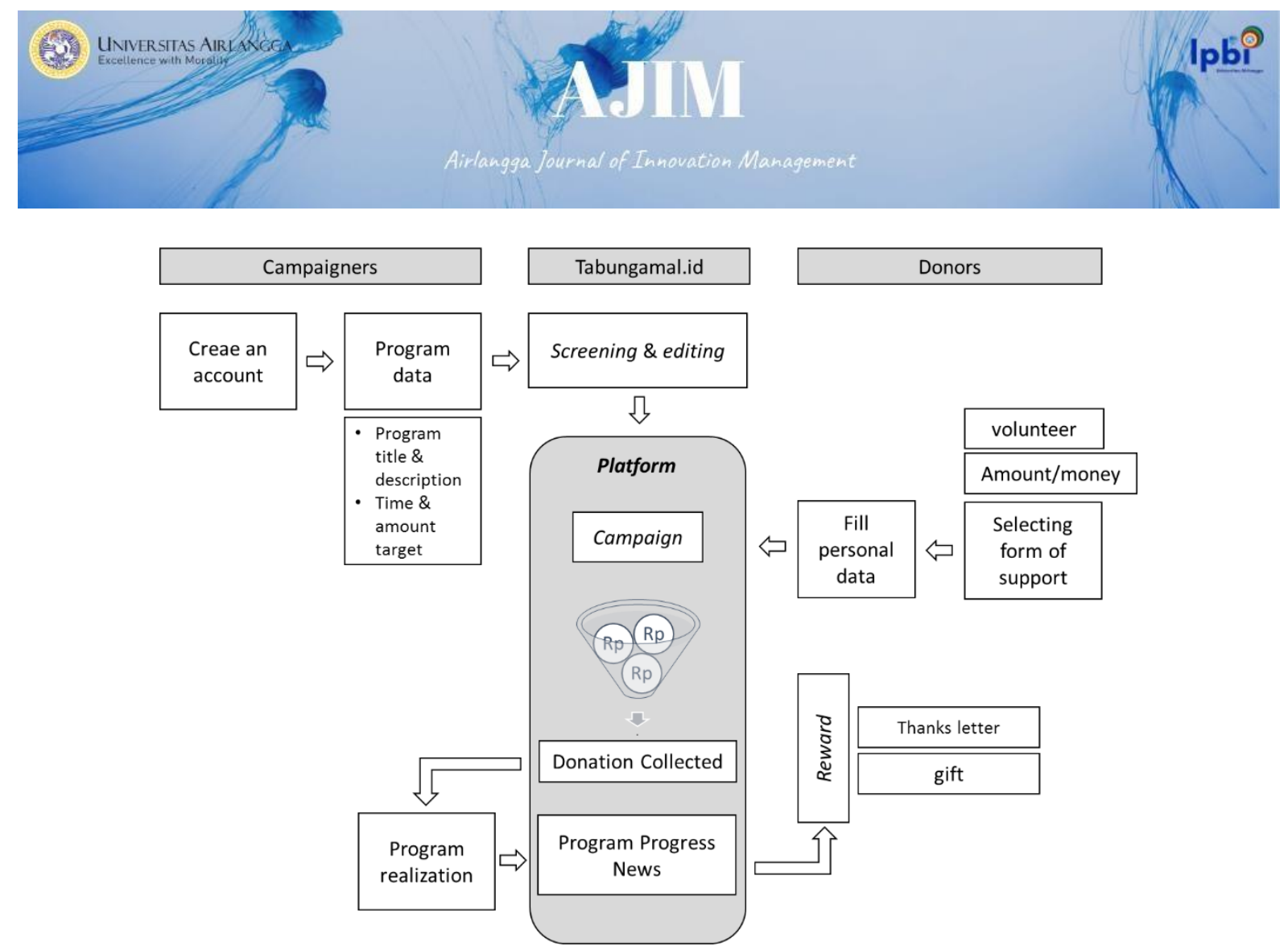

Figure 1

tabungamal.id Mechanism

Source: Research Result (2021)

The fundraising mechanism in tabungamal.id begins with creating a campaigner account on platform. At this stage, campaigner is required to fill in some data and then be verified by tabungamal.id team. Once account has been successfully created, campaigners can fill out a campaign form. Campaign form contains program data such as program title and description, photos, funds target, and time target of the fundraising. Furthermore, tabungamal.id team will do screening and editing. After that, campaign can appear on platform.

Donors interested in donating to a program will be directed to provide support. Support can be in form of amounts or volunteering. Before transfer process, donor will fill in some data such as donation amount, name, email, phone number, and comments (optional). Then donor will choose a payment method for transfer process. Successful or failed transfer process will be informed to donor's WhatsApps. Donor name and donation amounts will be displayed on platform.

tabungamal.id mechanism uses principle of keep it all. This principle allows campaigners to collect donations even if they have not reached target. Automatic donation withdrawals will be shown in platform. Once program is developed, campaigner will upload latest news from program on platform and notify donors' emails and whatapps. This is feedback from campaigner to donors.

\section{B. Risk Transformation}

Risk transformation is crowdfunding function as a neutral and objective party that assesses feasibility of program from campaigners (Haas, Blohm, \& Leimeister, 2014). The assessment and selection process conducted by tabungamal.id are campaigner assessment, program assessment, and post-donation monitoring.

The first campaigner assessment process is based on network owned by tabungamal.id, for example when tabungamal.id invites LAZIS branch to raise funds, then credibility of party has been 


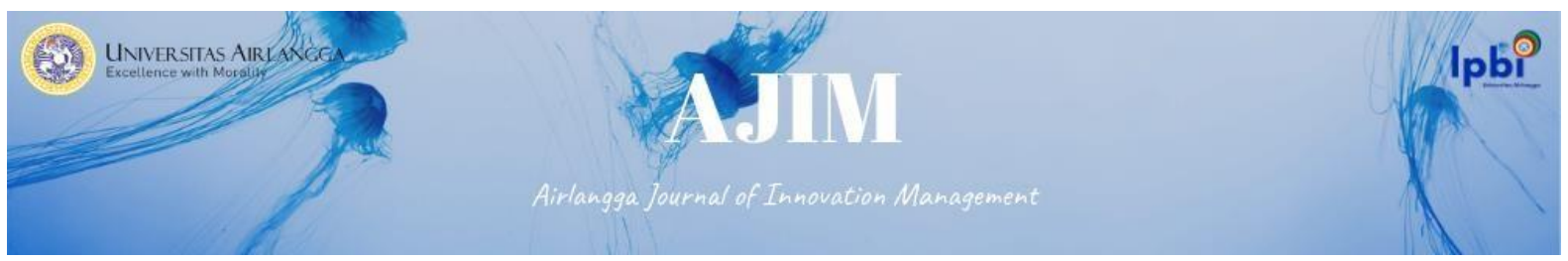

confirmed. Assessment through this network was also done by donors tabungamal.id when it will determine decision of donations, where donors will tend to donate to program with campaigners they know. Second assessment is based on identity and legality of campaigner during creating an account. Then continued with third assessment, by looking at commitment of campaigners. Highly committed campaigners will be easily contacted by tabungamal.id when there are incomplete or unclear files, while those who do not have a commitment tend not to respond, which leads to the failure of campaign posts.

Assessment program is to assess suitability of program with value of tabungamal.id namely Qur'an education. Second review process is to check completeness of data required for campaign such as activity descriptions and photos. If data is incomplete, campaign process cannot be done until data is completed and following provisions. This is in line with commitment aspect of fundraiser mentioned in previous point.

Campaigners who have collected their donations are asked to provide a report. The report is uploaded by campaigners on platform in form of photo documentation and captions. While financial statements have not been applied by tabungamal.id. Reports of program developments have opportunity to increase donor trust in campaign.

\section{Information Transformation}

Information is a function to provide information about program to donors and as a place for both parties to exchange information (Haas, Blohm, \& Leimeister, 2014). The tabungamal.id strategies on information transformation aspect are as follows:

\section{1) Provide Information}

The tabungamal.id platform has main function of providing a variety of information as a basis for donors to decide on their donations. On tabungamal.id, donors get the main information from the program title and description. Title and description of project showing details of purpose and intent of campaigner's program. Each campaign has its uniqueness that distinguishes one campaign from another, so it can interest the donors. Tabungamal.od also show the campaigner profile but only contains photos and names of campaigners. Sometimes that information is explained more detail in description column. Information about campaigners also plays an important role in donation decisions.

Another information on tabungamal.id platform are time and amount target of fundraising that delivered through summaries that make it easier for donors to understand information. Tabungamal.id also updates design of display on tabungamal.id platform, such as selection of images, colors and fonts that are comfortable in eyes will make it easier for visitors to retrieve information.

Tabungamal.id also have news columns and donor columns as a place where campaigner and donors exchange information. Through news column, campaigners can provide information about development of program to donors and potential donors. Meanwhile, donor column becomes donors' support information to campaigners. In addition, both columns can be useful for potential donors in deciding their donation decisions.

\section{2) Bulding a Network}

Tabungamal.id has the function of building a network and creating relationships between various parties. Tabungamal.id build a network between campaigners and donors by providing a 


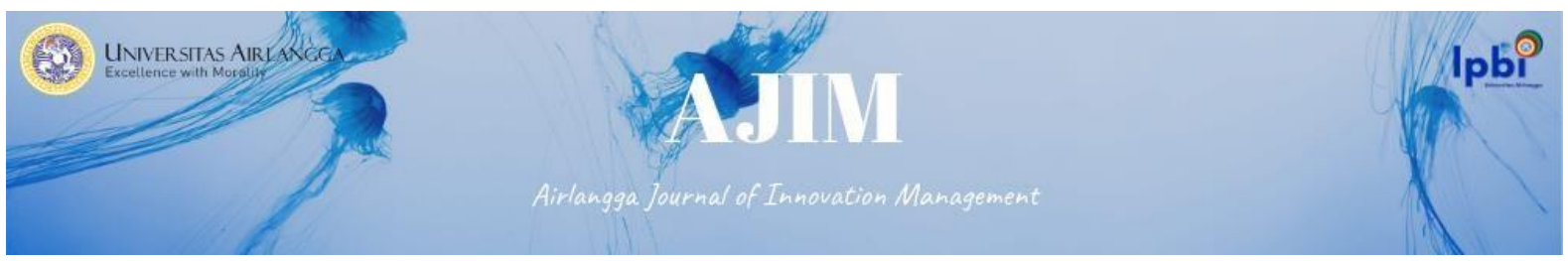

place to exchange information through news and donors columns. In addition, tabungamal.id also provide notifications.

Tabungaml.id also build a network with new visitors and returning visitors. New visitors are first-time visitors to tabungamal.id and have never donated. To build a network with these new visitors, tabungamal.id implement several strategies, among others: (a) education through social media; (b) both online and offline advertising; (c) online volunteers. Returning visitors are old visitors who have donated through platform. Notifications play an important role for tabungamal.id to maintain relationships with returning visitors. There are two types of notifications delivered to donors: 1) transaction notifications; and 2) notification of program progress. The notification is delivered via whatsapp blast and email.

\section{The Role of Crowdfunding based Donation Mechanism in Al-Qur'an Education Development}

The mechanism of crowdfunding-based donation tabungamal.id has 3 roles in Al-Qur'an education development, as follows:

\section{Role of Crowdfunding-based Donation Mechanism in Reducing Al-Qur'an Educational Gap}

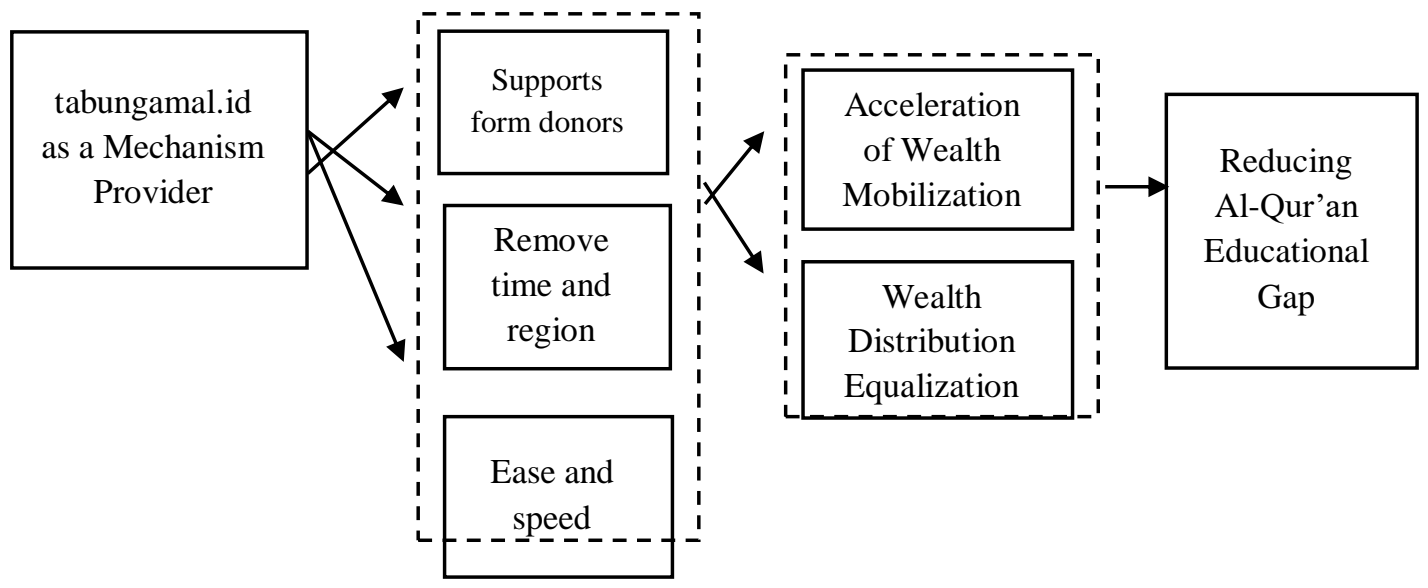

Figure 2

\section{The Role of tabungamal.id in Reducing Al-Qur'an Educational Gaps}

Source: Research Result (2021)

Role of tabungamal.id in reducing Al-Qur'an educational gap can be explained in figure 4.10. One of tabungamal.id functions is to provide mechanisms for successable fundraising. Through platform, campaigners get support from donors so programs can be implemented as intended. The tabungamal.id mechanism provides a place for donors and campaigners to connect within the online platform without being limited by region or time. Campaigners can reach donors in a wider area and donors can know campaigns from different regions.

Online mechanism makes activity run easier and faster. Like payment or transfer methods, donors don't need to come to place to donate. Donors also do not have to wait for opening or closing hours because donations can be transferred within 24 hours. In addition, tabungamal.id provides a simple administrative mechanism and does not require stacked document printouts. The quick and easy donation process can save costs and time of campaigners and donors. 


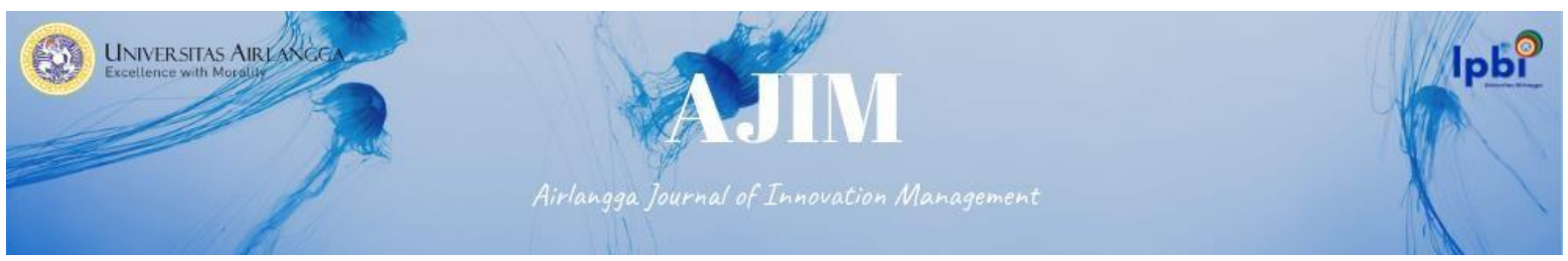

Effective and efficient fundraising mechanisms without any regional or time restrictions, encouraging acceleration of mobilization of wealth from donors to fundraisers. Accelerating mobilization of wealth will support wealth distribution equalization. The equalization of wealth becomes one part of Allah SWT's command contained in the pillars of Islam, namely zakat. It is also mentioned Qur'an surah Al-Hasyr verse 7, as follows:

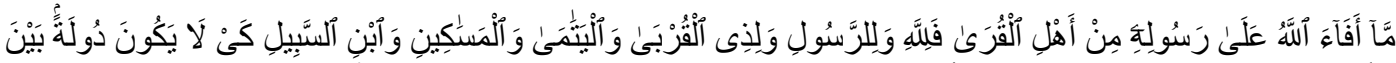

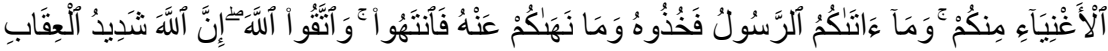

Meaning: What Allah gave as booty (Fa'i) to His Messenger (Muhammad saw) from people of townships, it is for Allah, Muhammad saw, the kindred, the orphans, the poor, and the wayfarer, in order that it may not become a fortune used by the rich among you. And whatsoever Muhammad saw gives you, take it, and whatsoever he forbids you abstain (from it) and fear Allah. Verily, Allah is severe in punishment (QS Al-Hasyr: 7)

Based on tafsir of (Shihab, 2001)., verse intends to assert that property should not only be power of a group of people but property must be circulated in community so that it can be enjoyed by all members of society while recognizing right of ownership and prohibiting monopoly. Gap is one of Al-Qur'an education problems. The gap between regions in Al-Qur'an education is evidenced by research of Ratnawati et al (2020) which mentions facilities and infrastructures supporting learning of Qur'an is growing rapidly in urban areas while in remote rural areas it becomes an obstacle because of limitations of learning media such as availability of book of Qur'an, teachers, and places. Facilities and infrastructure are important components to realize success of Qur'an education.

tabungamal.id become opportunity to reduce Al-Qur'an education gap between regions through crowdfunding mechanisms that have no regional boundaries. Crowdfunding mechanism allows campaigners to reach donors from a wider area to realize Al-Qur'an educational activities in region that lacks infrastructure. Involvement of donors from wider region can support Qur'an education program of remote areas to run goals to be achieved. Tabungamal.id prove this with a campaign aimed at Qur'an education in a remote border area. In tabungamal.id several campaigns raise scholarship for poor students' and teacher welfare. So that students and teachers who belong to lower class economy can carry out Qur'an learning activities through donations from donors. Thus, donation crowdfunding platforms can be a solution to educational gap of Qur'an, both interregional gaps and economic gaps.

Role of Crowdfunding-based Donation Mechanism in Supporting Al-Qur'an Learning Innovation

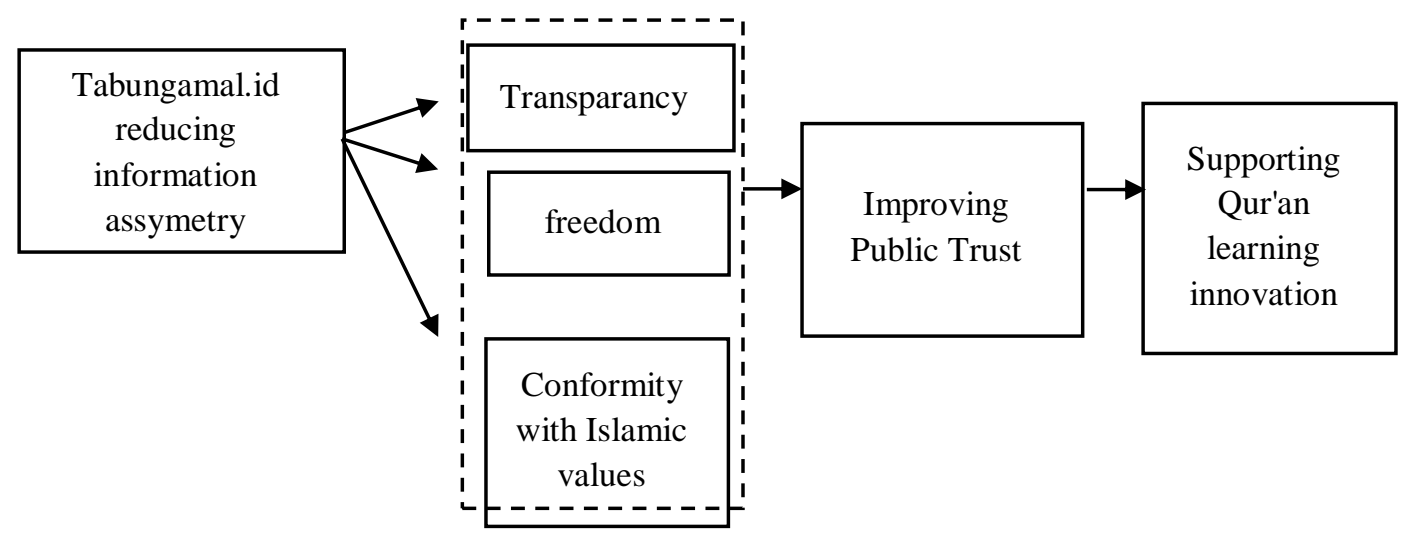

Figure 3 


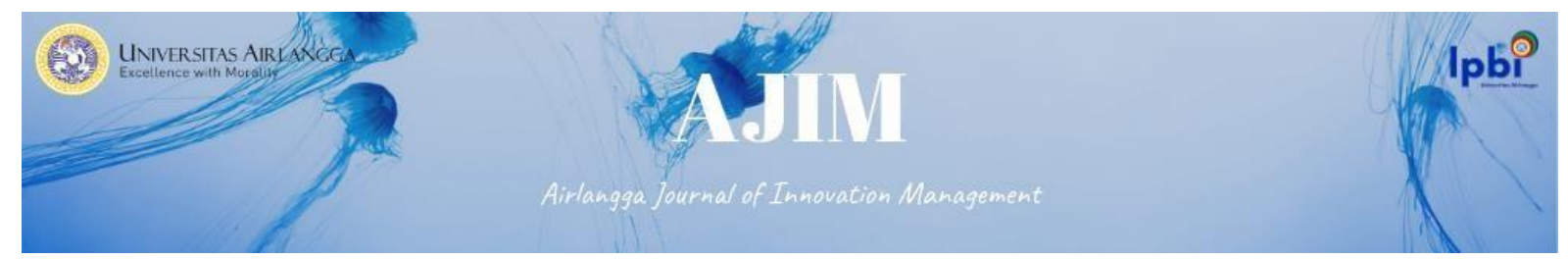

\section{The Role of tabungamal.id in Supporting Al-Qur'an Learning Innovation}

Source: Research Result (2021)

The role of tabungamal.id in supporting Al-Qur'an learning innovation can be explained in figure 4.11. Crowdfunding mechanism has an important function in reducing information asymmetry between campaigners and donors. Information asymmetry is a condition in which one party has more control over information than other. Transparency is important in crowdfunding activities. On tabungamal.id platform, donors can find out and choose for themselves where their donations will be distributed. Similarly, fundraisers can also provide information on development of program through platform. So information is not only known by one of parties.

Before appearing on platform, information about campaigners and programs has been verified by tabungamal.id team. So, donors do not have to worry about fraud that may occur, for example, halal activities of existing program. Tabungamal.id is one of platforms that $100 \%$ supports Islamic da'wah, where platform will not display a campaign that intersects with Islamic values.

Public trust in institution will help company to achieve its mission vision (Behl, Dutta, Sheorey, \& Singh, 2020). In Islam, trust is better known as amanah which means to be trusted. Allah commands His servants to always be trustworthy, this is contained in the Quran Surah Al-Mu'minun verse 8 , as follows:

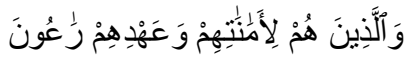

Meaning: "And those who are faithfully true to their amanat and to their covenants (QS AlMu'minun: 8)

In tafsir of al-Mishbah, this verse means that a believer always keeps whatever is entrusted to him, whether wealth, words, or deeds. Also always keep the promise to God and others, do not betray or break the promise (Shihab, 2001).

In crowdfunding mechanism, trust plays an important role in success of fundraising (Behl, (Behl, Dutta, Sheorey, \& Singh, 2020). Transparency is one form of effort to increase public trust in philanthropic institutions. Soleh (2020) states that lack of transparency and accountability of Islamic philanthropic institutions causes low trust of muzakki in Islamic philanthropic institutions, which will affect not optimal fundraising. In this case, crowdfunding mechanism can increase public trust through transparency of campaign information.

Campaigns that get trust from donors will get a lot of support from donors, this can be seen from amount of donations collected. To make a successful campaign, fundraisers are not only required to provide transparency but also required to create programs that can attract donations. Through donations made to sympathetic donors, fundraisers will compete with each other to create innovative and exciting programs.

Based on Ratnawati et al (2020) one of Qur'an learning problems is lack of transformation and innovation so goal of Al-Qur'an education will not be maximally achieved. Innovations in the Al-Qur'an education field include: Qu'ran learning process innovation, institutional development innovation, and innovation of technology application in Qur'an learning (Yusuf, 2017). There is one campaign on tabungamal.id platform that supports Qur'an education innovation is procurement of mobile tilawati that will support students to learn Qur'an through android that can be accessed 24 hours. Thus, crowdfunding mechanism can emerge various innovations that can support progress of Qur'an education program. 


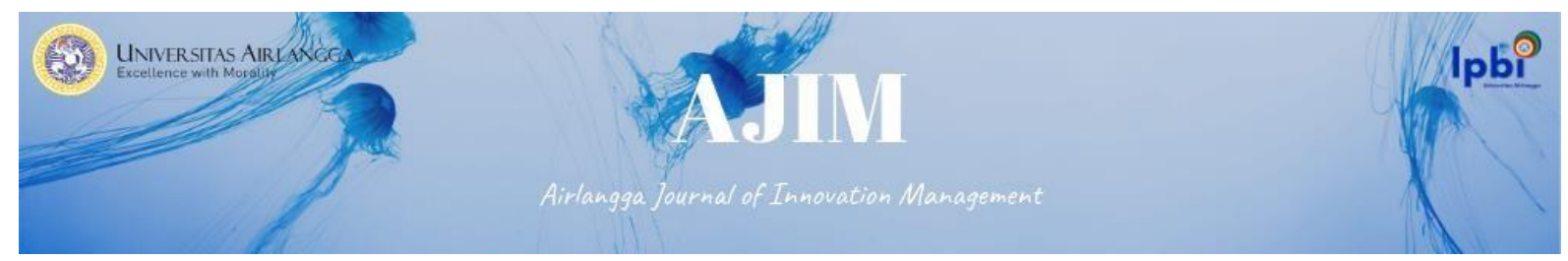

Role of Crowdfunding-based Donation in Increasing Public Participation in Advancement of Al-Qur'an Education

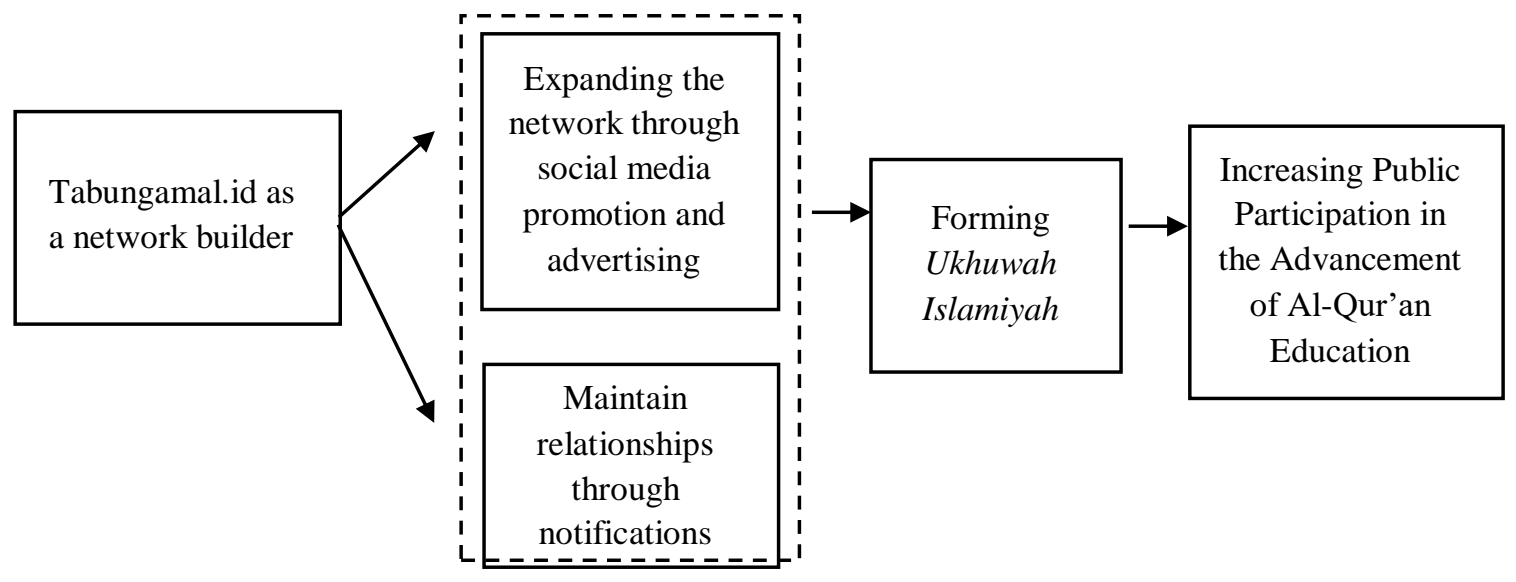

Figure 4

The Role of tabungamal.id in Increasing Public Participation in the Advancement of AlQur'anEducation

Source: Research Result (2021)

The role of tabungamal.id in increasing public participation in advancement of Qur'anic education can be explained in figure 4.12. Crowdfunding mechanism serves as an inter-party network builder. Success of fundraising in tabungamal.id relies heavily on networking systems. Tabungamal.id allow for a wider network due to open nature of platform. As mentioned earlier, crowdfunding mechanism can remove boundaries of region, so that fundraising activities can reach more donors in a wider area.

In building a sustainable relationship with donors, tabungamal.id provide a variety of information, both on platform and off platform. Information shared externally is expected to bring donors to visit platform. While information shared on internal platform aims to explain campaign in more detail attracting donors to donate

Furthermore, maintaining relationships with donors, tabungamal.id provide notifications related to progress of fundraising. New program campaign notification is expected to be a reminder for donors to donate. While program progress notification will be a satisfaction for donors so it will motivate return and donate on platform.

Tabungamal.id is a Qur'an-oriented platform, which has a target market of people who care about Qur'an. Network formed between all parties involved in tabungamal.id is based on common purpose of caring for Qur'an education. Existing network indirectly forms ukhuwah islamiyah. Ukhuwah Islamiyah is an inner bond that gives rise to a deep sense, full of tenderness, love, and respect to everyone who is equally bound by akidah Islamiyah, faith, and piety (Ulwan, 1985). Importance of ukhuwah Islamiyah is mentioned in the Qur'an Sura Al-Imran verse 103 as follows:

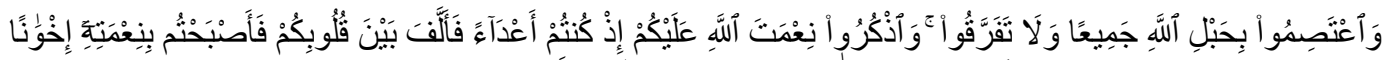

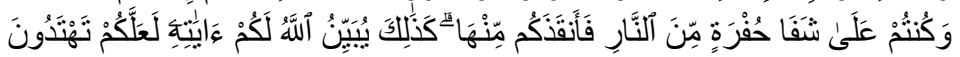

Meaning: "And hold fast, all of you together, to the Rope of Allah, and be not divided among yourselves, and remember Allahs' favour on you, for you were enemies one to another but $\mathrm{He}$ 


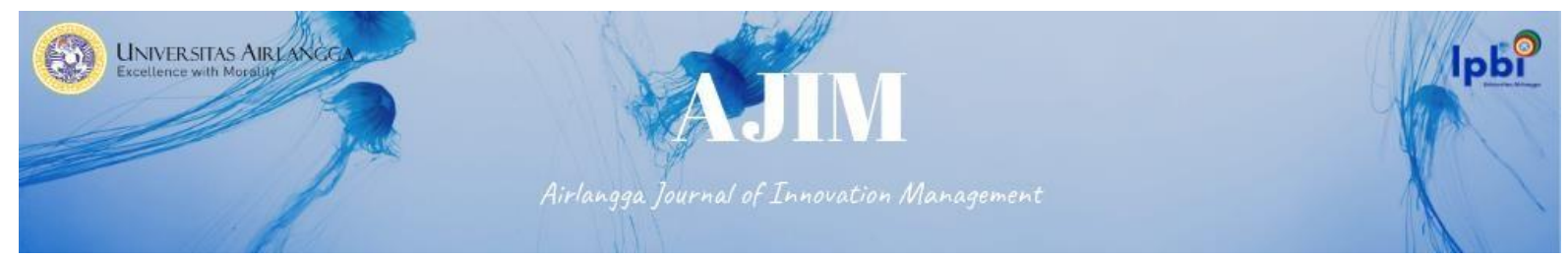

joined your hearts together, so that, by His Grace, you became brethren (in Islamic fiath), and you were on the brink of a pit of fire, and He saved you from it.

Thus Allah makes His Ayat clear to you that you may be guided" (QS Ali Imran: 103).

M. Quraysh Shihab (2002) interprets QS Al-Mu'minun verse 8 as an order to knit unity over Islam and prohibition to do something that leads to division. In this verse it is also affirmed that unity of heart, love, and brotherhood through the of Islam is a gift of Allah SWT.

Based on Alawiyah research (2014) lack of support and community participation is a challenge for education. According to him, responsibility to organize an advanced education is a shared responsibility, not just an educational institution. While based on Amaliyah research (2020), ukhuwah islamiyah influences t $a^{\prime}$ wun attitude or helpful attitude. Thus, network or ukhuwah islamiyah formed through a crowdfunding platform tabungamal.id can increase knowledge and participation of the community in success of Islamic education.

Three roles of crowdfunding mechanisms in Qur'an education development above can be explained by figure 5 below:

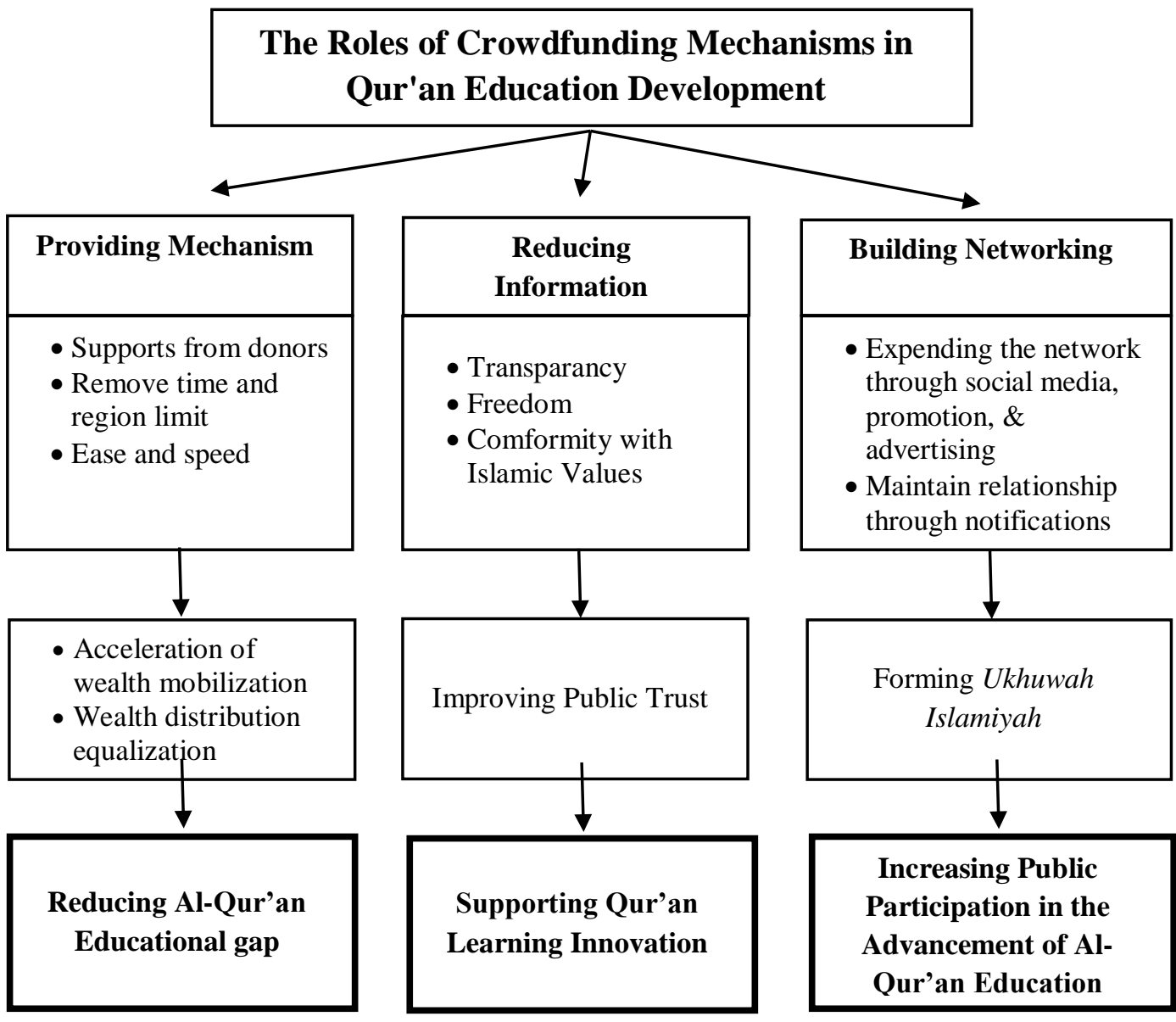

Figure 5

The Roles of Crowdfunding Mechanisms in Qur'an Education Development

Source: Research Result (2021) 


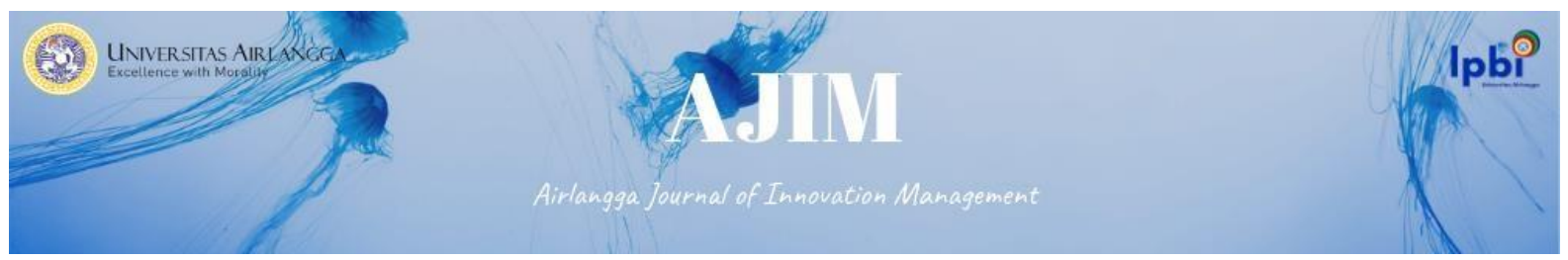

\section{Conclusion}

Tabungamal.id as a crowdfunding-based donation platform has three roles in Al-Qur'an education development: (1) reducing Qur'an educational gaps ; (2) supporting Qur'an learning innovation; (3) increase public participation in Qur'an education development. Three roles can be briefly explained as follows:

1. tabungamal.id provide easy and fast fundraising and donation mechanisms, and not limited by place or time. Such an effective and efficient mechanism can accelerate mobilization and equalization of wealth distribution, so Al-Qur'an educational gap can be reduced.

2. tabungamal.id provide transparency and freedom for donors in assessing each campaign. Donors who believe in a campaign will channel their donations to program. Thus motivating campaigners to campaign creative programs that can appeal donors. This will support innovation of learning Qur'an.

3. tabungamal.id provide information to various parties through internal platforms and external platforms such as social media, as an effort to form ukhuwah islamiyah with a shared motivation that is to advance Qur'an education. Ukhuwah Islamiyah that has been formed will increase community participation for Al-Qur'an education development.

Islamic philanthropic institutions should maximize the role of the crowdfunding mechanism to support fundraising activities. This study shows that crowdfunding has its advantages compared to another online fundraising mechanism, which doesn't just stop at fundraising activities but also the development and sustainability of the program. Subsequent research should exemine the same topic with more research objects

\section{References}

Ascarya, \& Yumanita, D. (2018). Analisis Rendahnya Pengumpulan Zakat di Indonesia dan Alternatif Solusinya. 6.

Bahjatulloh, Q. M. (2016). Pengembangan Pemberdayaan Ekonomi Masyarakat Melalui Kegiatan Filantropi. Jurnal Penelitian Sosial Keagamaan, 478.

BAZNAS. (2020). Statistik Zakat Nasional 2019. Jakarta: Badan Amil Zakat Nasional Sub Divisi Pelaporan.

Behl, A., Dutta, P., Sheorey, P., \& Singh, R. K. (2020). Examining the Role of Dialogic Communication and Trust in Donation-based Crowdfunding tasks Using Information Quality Perspective. The TQM Journal.

Dewi, I., Bukhori, I., Sopwandin, I., \& Hidayat, A. (2020). Implementasi Dana ZISWAF Dalam Pendidikan Islam. Jurnal Islam Nusantara Vol. 04 No.01, 33.

Ditpdpontren. (2020). Pangkalan Data Pondok Pesantren. Diambil kembali dari Ditpdpontren Kemenag: https://ditpdpontren.kemenag.go.id/pdpp/statistik

Gierczak, M. M., Bretschneider, U., Haas, P., Blohm, I., \& Leimeister, J. M. (2015). Crowdfunding: Outlining the New Era of Fundrising. FGF Studies in Small Business and Entrepreneurship, 723.

Haas, P., Blohm, I., \& Leimeister, J. M. (2014). An Empirical Taxonomy of Crowdfunding Intermediaries. Thirty Fifth International Conference on Information Systems, Auckland, 5-6. 


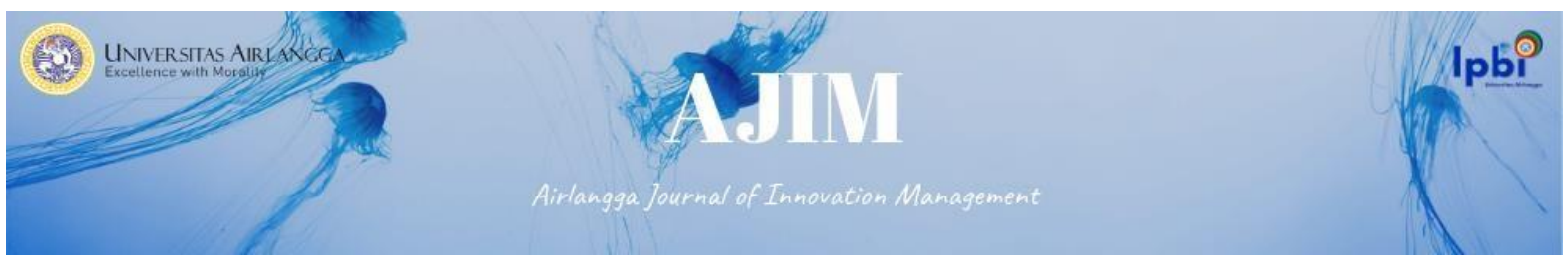

Hendratmi, A., Sukmaningrum, P. S., Ryandono, M. N., \& Ratnasari, R. T. (2019). The Role of Islamic Crowdfunding Mechanisms in Business and Business Development. Journal of Business and Economics Review.

Huda, N., \& et al. (2014). Solutions to Indonesian Zakah Problems Analytic Hierarchy Process Approach. Journal of Islamic Economics, Banking and Finance Vol 10(3), 123-139.

infoDev. (2013). Crowdfunding's Potential for the Developing World. Washington DC: The World Bank.

Ja'far. (2018). Problematika Pendidikan Pondok Pesantren di Era Globalisasi. EVALUASI Vol. 2 No. 1. Kasdi, A. (2016). Filantropi Islam untuk Pemberdayaan Ekonomi Umat. Iqtishadia Vol. 9 No. 2, 231.

Kemendikbud. (2020). Indonesia Education Statistics in Brief. Jakarta: Kementerian Pendidikan dan Kebudayaan.

Latief, H. (2013). Filantropi dan Pendidikan Islam di Indonesia. 127.

Linge, A. (2015). Filantropi Islam Sebagai Instrumen Keadilan Ekonomi. Jurnal Perspektif Ekonomi Darussalam Vol. 1 No.2, 157.

Manara, A., Permata, A., \& Pranjoto, R. (2018). Strategy Model for Increasing the Potential of Zakat Through the Crowdfunding-Zakat System to Overcome Poverty in Indonesia. Special Issue on Zakat Conference 2018.

Ratnawati, D., Abidin, Z. A., \& Zulfikar, E. (2020). Problematika Pembelajaran Al-Qur'an di Era Industri Dalam Konteks Indonesia. Jurnal Kependidikan Islam Vol. 6 No.1.

Shihab, M. Q. (2001). Tafsir Al-Mishbah: Pesan, Kesan, dan Keserasian Al-Qur'an . Jakarta: Lentera Hati.

Ulwan, A. N. (1985). Persaudaraan islam. Jakarta: Al-Islahy press.

Ulya, N. (2018). Legal Protection of Donation-based Crowdfunding Zakat on FInancial Technology. International Conference of Zakat 2018 Proceedings.

Ummah, K. A., Riyadi, A., \& Herianingrum, S. (2018). Pola Implementasi Alokasi Zakat dalam Penyediaan Pendidikan Bagi Kaum Dhuafa. Jurnal Ekonomi dan Bisnis Islam Vol.3 No.2, 250.

Ustama, D. (2009). Peranan Pendidikan dalam Pengentasan Kemiskinan. Jurnal Ilmu Administrasi dan kebijakan Publik.

Yahya, F. (2015). Problem Manajemen Pesantren, Sekolah, Madrasah: Problem Mutu dan Kualitas Input-Proses-Output. eL-Tarbawi Vol.8 No.1.

Yin, R. (2016). Qualitatif Research From Start to Finish. New York: A Division of Guilford Publications, Inc.

Yusuf, M. J. (2017). Metode Iqra' : Kajian Inovasi Pembelajaran Al-Qur'an. Jurnal Edukasi.

Zulfian, D. (2020). Faktor-Faktor yang Memengaruhi Keputusan Berdonasi Secara Online Melalui Platform Financial Technology Crowdfunding. 